\title{
Unity in Adversity: Reflections on the Clinical Movement in South Africa ${ }^{1}$
}

\section{Willem de Klerk²}

\section{Introduction}

Not long after I joined the Wits Law Clinic in January of 1997, I was seconded by our Director to attend a workshop hosted by Rhodes University Law Clinic in Grahamstown. The workshop was to be presented by the Association of University Legal Aid Institutions, or AULAI as it is commonly known. ${ }^{3}$ As a new recruit to our law clinic I barely knew of the existence of other university law clinics in South Africa, let alone a national association of law clinics. No-one at our clinic bothered to inform me what the workshop was all about, and I, being only concerned really with the adventure of travelling to a beautiful part of the Eastern Cape, never bothered to ask. So, I set off to Grahamstown in blissful ignorance of the events that were to follow, events that, as it turned out, shaped my involvement with law clinics in South Africa.

During those few days in Grahamstown I met with lawyers working at law clinics from all corners of South Africa, many of them from universities I had not even known existed. There were people from universities outside of South Africa, including Lesotho, Swaziland and Namibia, who were either intending to set up clinics or in the process of doing so. There were lawyers who had been in practice for twenty years, and those who were busy completing their articles of clerkship. Some had their roots in academia and others had a long history of private practice behind them. It was a diverse group of people, all with one thing in common: They were all part of what has become known amongst clinicians in South Africa as the clinical movement. For me, it was a revelation.

At that particular workshop there was a huge dispute, concerning, as is often the case, money. The details of the dispute are not important, but what was interesting was the way in which this dispute

1 Paper delivered at the 5th International Journal for Clinical Legal Education Conference held at Johannesburg on 9-10 July 2007.

2 Adjunct Professor, University of the Witwatersrand Law Clinic, Willem.deklerk@wits.ac.za

3 On the history of Aulai and the impact it has had on the clinical movement, see Danny Wimpey and Shaheda Mahomed "The Practice of Freedom The South African Experience", paper delivered at the Fourth International Journal of Clinical Legal Education and Eighth Australian Clinical Legal Education Conference held at London, July 2006 (copy in author's possession). 
played itself out. After a session of unrestrained confrontation, tempers were calmed and by day two, everyone seemed to be the best of pals. As an outsider at that stage, I was most impressed at this apparent ability to overcome conflict and move on. In fact, it reminded me a bit of arguments amongst siblings, where peaceful coexistence must inevitably prevail for the simple reason that one is stuck with one's siblings. Over my years in the clinical movement I have witnessed on many occasions how law clinicians in South Africa, irrespective of their diverse backgrounds, behave as members of the same family.

One explanation for this cohesion amongst clinicians may have something to do with us as people. During that same Grahamstown workshop, the organisers saw it fit to subject all of us to the Myers-Briggs Type Indicator ${ }^{4}$, a type of personality test that groups people according to certain personality preferences ${ }^{5}$. The results were quite interesting. It showed what seemed to be a trend amongst the clinical lawyers present to lean towards being the "feeling types" as opposed to the "thinking types", meaning that when making decisions, we generally tend to first look at people and special circumstances, rather than at logic and consistency. The facilitators compared our results with that obtained from lawyers at a large commercial law firm and the results seemed to show that our group was indeed quite different from the typical commercial lawyer, who generally tends to be more of the "thinking type". More recently, I was very interested to read a paper delivered by Dr. Colin James at the Clinical Legal Education conference held in Melbourne during July of $2005^{6}$, where the learned author refers to research done on American law students. The research showed that, on the same Myers-Briggs Type Indicator, the vast majority of law students are the "thinking types" as opposed to the "feeling types". It also showed that those who were more inclined to "feeling" were more likely to drop out of law school. ${ }^{7}$ So, maybe one of the reasons why clinicians seem to get on so well with each other is because it is a miracle any of us made it through law school!

But I suspect that the reason why clinicians are inclined to bond, has a lot to do with external factors. In all the years that I have been practicing in the clinic, I have yet to find a simple answer to the question: "So, what is it that you do?" I have tried the "I am a lawyer" response, but invariably one is then confronted with the question "So, what type of lawyer are you?" Somehow I don't think it's a good idea to answer "the feeling type", so I normally say something like "I'm a public interest lawyer" or "I do work for the poor". The usual response then, is "So then you're a legal aid lawyer?" which is not right either as legal aid lawyers work in an entirely different environment. Saying that I'm a law teacher or academic is dicey too, because the typical question then would be, "So what subject do you teach?" There is no clear answer to this question either, as clinical legal education is not a subject but a teaching methodology and besides, it's usually not a good idea to delve into these issues with people whom you have just met.

I suspect that this simple inability to describe what clinicians really do, in terms that are easily

4 For more information, see www. myersbriggs.org/my-mbti-personalitytype/mbti-basics (last visited April 2007).

5 These are: Extraversion versus Introversion; Sensing versus Intuition; Thinking versus Feeling; and Judging versus Perceiving. See ibid.

6 Colin James "Seeing Things as We Are - Emotional Intelligence and Clinical Legal Education" paper delivered at the Third International Journal of
Clinical Legal Education and Eighth Australian Clinical Legal Education Conference held in Melbourne, Australia in July 2005. A copy of the paper is in the author's possession. [Editor's note: A version of this paper can be found in [2005] International Journal of Clinical Legal Education 123-149].

7 At page 5, footnotes 21 and 22 . 
understood by most people, has a lot to do with the unity amongst them. Law clinicians are fringe actors. They are largely institutional misfits, both in legal education as well as legal practice.

Law clinicians are not regular lawyers. Regular lawyers have nice offices with comfortable chairs and offer their clients tea and coffee while they wait. Regular lawyers have clients who arrive for consultations in motor vehicles, who live in proper houses and who have access to internet. They charge for what they do and generally will not do much unless they are paid for it. Regular lawyers conduct a business. They have fee targets, overhead expenses and need to worry about things like marketing and competition. Regular lawyers, generally, have little time to reflect on issues like social justice or access to legal services for the poor.

Law clinicians, while mercifully free from much of the day to day stresses that characterise the life of a regular lawyer, have other dynamics to cope with. Being released from having to reach a monthly fee target is a welcome respite only until you are burdened with the huge demand for free legal services and the difficulties that come with public interest lawyering. Clients at law clinics are generally poor, uneducated and marginalised from mainstream society. They tend to present to the clinic lawyer a rather large package of problems, half of which have nothing to do with the law and the other half so intertwined with poverty that their actual legal problems are often very hard to extract. Formulating the mandate is only half the battle won, as the enforcement of clients' rights pose particular difficulties, especially in South Africa where many of our clients live in communities where the rule of law commands little respect. ${ }^{8}$

The cost of private legal services makes for an important distinction too. Litigation is generally very expensive. This forces clients to carefully consider the parameters of the mandate given to the lawyer. With free legal services the temptation is too great to see, and treat, the lawyer as a general therapist or a debt counsellor or marriage counsellor. In clinical practice, clients often tend to give the lawyer the nearly unbearable mandate of simply 'putting right what is wrong', irrespective of legal complexities or the duration it might take. The challenge presented to the clinic lawyer is to fashion effective relief for clients whose lives and legal problems are so saturated with poverty, illiteracy and general disadvantage, that the law as a tool to fight injustice is often not very effective.

Another difference between regular lawyers and clinic lawyers is the instruments used to measure success. Lawyers in private practice typically measure their success against the amount of fees they write during any particular period. Clinic lawyers do not have any one clear and simple tool to measure of their success. Some say we should look at the number of matters completed during any particular period, in other words, how many files you close per month. This is the favourite measure used by state funded legal aid lawyers and has resulted in many questions about the quality of their work. The problem of this measure is, of course, that is has no bearing on the complexity or quality of the work done. Other say we should look at our success rate, meaning the

8 One example of the breakdown of legal process could be found in issues around registration of ownership of immovable property, particularly in many of South Africa's former black townships. Often, the deeds registry system is not applied, with the result that de facto ownership bears little resemblance to legally registered ownership. This is particularly problematic when it comes to intestate deceased estates, where the estate was never wound up and the lawful heirs have never received transfer of the property into their names. The property in the estate is often regarded by the heirs as a 'family home' and rights of occupation are determined arbitrarily by the stronger heirs. For one heir to exercise any rights to the property, a complex and time consuming set of legal procedures need first to be followed. Even if these procedures are implemented successfully, the enforcement of occupancy rights is often sabotaged by the inability of the person to effectively take control of the property in communities where respect for the rule of law is absent. 
percentage of cases you conclude successfully. The problem with this approach is that it is very hard to define what should be considered a 'success' and what not. ${ }^{9}$ So clinic lawyers are often left to their own devices when it comes to judging their success, a rather subjective and unrewarding exercise. Practicing law in a busy clinic environment without an effective method to judge success could easily lead to what we have seen and described as 'burnout'. Part of the challenge in being a clinical lawyer is to develop a sensible approach to your lawyering work and what it is you would like to achieve.

But the most fundamental difference between regular lawyers and clinic lawyers is the fact that clinic lawyers use the practice of law as a vehicle to educate students. Practicing law as a teacher is very different from practicing law as a purely commercial pursuit. The financial interest that a lawyer in commercial practice has in his or her legal matters is absent in a clinical setting, but is replaced by the educational interests of students. Students pay good money to complete clinical courses and have legitimate expectations of the benefits they should receive in return. The teaching that takes place in a clinic should therefore never be incidental or secondary to the practice of law. Teaching students remains the core business of law clinics. A good clinical lawyer must, for example, be aware of different approaches to lawyering ${ }^{10}$ but also his or her own approach, whether consciously or unconsciously adopted. A good clinical lawyer should communicate to students ${ }^{11}$ the different approaches and make them reflect on the relative merits or demerits of each. A good clinical lawyer should be an example to students on how to practice law professionally and ethically 12 . One purpose of clinical experience remains "to set a standard for the practise of law" and it is said that "even if in practice the standard cannot always be met, the student should now what the standard is." 13

A good clinical lawyer should be conscious of the educational significance of working with the poor. Many law students come from advantaged backgrounds and have no first hand exposure to the needs of the poor. From university they may proceed to join a corporate law firm and build their careers in total ignorance of what is really happening at grass-roots level. The clinical experience forces students to assess the role of lawyers in society. This learning curve is particularly important in South Africa, where there are vast disparities between rich and poor and where the majority of lawyers occupying senior positions in the legal profession today had been schooled at a time when the law was used predominantly as an instrument of suppression. In our new found democracy lawyers have a very important role to play. This role has been described by Judge Mahomed Navsa ${ }^{14}$ as a "sacred duty to contribute towards the preservation and

9 Rarely is the outcome of any particular case clearly definable as a 'success' or not. At the University of the Witwatersrand Law Clinic, we have devised a range of possible outcomes when a file is eventually closed, including "partial success"; "abandoned"; and "no merit", all of which are equally vague.

10 For example the 'adversarial lawyer'; the 'merchant lawyer' and the 'responsible lawyer'. See Curran, Dickson and Noone "Pushing the boundaries or preserving the status quo?" (2005) draft paper delivered at the $3 \mathrm{rd}$ International Journal of Clinical Legal Education Conference held at
Melbourne, Australia during July 2005 fn 29 to 34 (copy in author's possession). [Editor's note: Paper published at: [2005] International Journal of Clinical Legal Education, 104-122.]

11 Ibid at fn 28-9.

12 Ibid

13 See Franklin "The clinical movement in American legal education" (1986) 1 Natal University Law and Society Review 55 at 66.

14 Judge of the Supreme Court of Appeal of South Africa. 
strengthening of the rule of law in South Africa". ${ }^{15}$ Judge Navsa warned that, unless the Constitution "has meaning in the lives of all our citizens, it is not inconceivable that it will wither and die" 16 . Reflecting on these issues during university study is very important, and the clinic is the ideal place to do $\mathrm{so}^{17}$, for it is only once confronted with an actual client with an actual problem that the importance of concepts such as "justice " and "equity" becomes real. A good clinical lawyer should therefore practice law in a manner that is conducive to reflection on the values and obligations of legal practitioners in society.

Law clinicians are not regular law teachers either, or, more specifically, they are not generally regarded by regular law teachers as regular law teachers. Regular law school academics teach what is perceived to be regular law courses, such as the law of property, the law of delict (tort) or criminal procedure. Regular law school academics are not, as a rule, concerned with the dynamics governing the practical application of what they teach ${ }^{18}$. Regular law school academics enjoy permanent appointments as members of the academic staff with clear promotion tracks.

Most clinicians in South Africa are appointed as non-academic staff members on externally funded contract positions and have no clear promotion track. ${ }^{19}$ Moreover, clinical legal education is still seen by many law school academics as controversial and generally inappropriate in the law degree. To my mind, this approach defies all logic and I have yet to come across a coherent argument in defence of this approach. But as I understand it, the main reason why clinical programmes are deemed inappropriate at university level, is because they are perceived to be

15 The statement was made during a series of lectures presented to final year law students at various universities around South Africa during 2005. An edited version of this talk is contained as the introductory chapter in De Klerk (ed) Clinical Law in South Africa 2nd ed (2006) 1.

16 Ibid at 2

17 Roy Stuckey for example formulates one of the educational objectives of clinical courses to be the "Understanding the meaning of justice and the responsibility of all lawyers to strive to do justice". See "Ensuring Basic Quality in Clinical Courses" (2000) International Journal of Clinical Legal Education 47 at 51.

18 It has been said that "...the priorities of academic training for the (legal) profession are seen to be the imparting to students of a specialized body of knowledge as well as principles of theory organized systematically and the application of knowledge and theory to problem solving." Joan Church "Reflections on legal education" (1988) 1 Tydskrif vir die Hedendaagse Romeins-Hollandse Reg 153 at 158. The lack of practical training during law school study is a topic of seemingly endless debate. For
South African literature, see Chaskalson "Responsibility for practical legal training" (March 1985) De Rebus 116; Maharaj "The role of the law school in practical legal training" (1994) South African Law Journal 328; O’Regan "Producing competent graduates: The primary social responsibility of law schools" (2002) South African Law Journal 242 and Woolman et al "'Toto, I've a feeling we're not in Kansas anymore"” A Reply to Professor Motala and Others on the transformation of legal education in South Africa" (1997) South African Law Journal 30 at 50-54. The issue has also been raised in other jurisdictions. See Barry et al "Clinical Education for this Millennium: The Third Wave" (2000) Clinical Law Review at fn 141 where it is stated that "In the typical law school classroom, the world of practice is often regarded suspicion and sometimes even distain."

19 Peggy Maisels tabled a detailed report in this regard at the South African Law Teacher's Conference held in 2000. In 2006 the UWC Law Clinic tabled a discussion report with its law faculty, detailing the employment conditions of clinicians are various clinics in South Africa (copy of report with author). 
courses or subjects that deal in practical legal training, and practical legal training is traditionally seen to be the responsibility of the profession and not universities. ${ }^{20}$

The problem with this view is that it is premised on two incorrect basic assumptions. Firstly, clinical legal education is not a course or a subject, as it is typically 'packaged' in the law degree, but is in fact a teaching methodology 21 . It is a process whereby knowledge, skills and values are combined in a live interaction with an actual client. Academic legal education on the other hand uses the traditional classroom method of instruction as its predominant teaching methodology 22 , whereby law is taught in a systematically organised manner. It can be said that if academic legal education does business at wholesale, then clinical legal education does it at retail. ${ }^{23}$ The neatly packaged law as taught using the academic methodology is deconstructed using the clinical methodology, to expose students to the unstructured nature of law-in-action. Clinical legal education is a methodology that transcends the artificial boundaries imposed by academic training. It is essential in demonstrating to students the difficulties in applying theory to practice. Although these two methodologies are vastly different from each other, the ultimate goal of both is very much the same, namely to produce well-rounded and competent law graduates ${ }^{24}$.

The second assumption, namely that clinical legal education is solely about practical legal training, is just plainly wrong. Elsabe Steenhuisen, formerly head of the University of Johannesburg Law Clinic, in her research identified seven goals of clinical legal education, only one of which relates

20 This is particularly so in commonwealth jurisdictions where admission to the profession is subject to the completion of a period of internship post university study. Joan Church (op cit note 16 at 157) for example states that education for the legal profession is seen to encompass three main components, being "academic" instruction at university; "practical/professional" training during internship; and "continuing legal education" for post-admission training. See also A Chaskalson "Responsibility for practical legal training" op cit note 16 at $116-7$ where the weaknesses of this system are exposed. The institutionalized prejudice against engaging with the practical at law school is however also prevalent in other jurisdictions. For example, the primary educational goals of law schools in the United States is said to "teach legal doctrine and analysis" with the case method of instruction still being the primary method of instruction and that "very few U.S. law schools have made a serious effort to integrate the teaching of knowledge, skills, and values..." See Roy Stuckey "The Evolution of Legal Education in the United States and in the United Kingdom: How one system became more faculty-oriented while the other became more consumer-oriented" (2004) International Journal of Clinical Legal Education 101 at 135 . The most pervasive reason for this, seemingly illogical, state of affairs has nothing to do with the desirability or need for practical programmes at law school, but basically boils down to law schools seeking to preserve the benefits of the status quo. See Kate O'Regan op cit note 16 at
248 (the author uses the terms "institutional resistance to change"); Hugh Brayne "A case for getting law students engaged in the real thing - The challenge to the saber-toothed curriculum" (2000) 34 The Law Teacher 17 at 20. See also Jeff Giddings "Unselfish acts: Sustainability in clinical legal education", paper delivered at the Third International Journal of Clinical Legal Education conference held at Melbourne during July 2005 (copy with author) at fn 193-4.

21 See Roy T Stuckey "Ensuring Basic Quality in Clinical Courses" (2000) International Journal of Clinical Legal Education 47 at 49.

22 See Woolman et al (op cit note 16 at 37 and further) where the results of a survey amongst law schools in South Africa, dealing with teaching methods, are set out.

23 I have adapted the analogy used by Jerome Frank "A Plea for Lawyer-Schools" 1947 (8) The Yale Law Journal 1303 at 1310 , where the learned author states that "Never forget that courts do business at retail, not wholesale".

24 Producing competent graduates has been said to be the ultimate aim of university law schools. See Kate O'Regan op cit n16. See also Osman "Meeting quality requirements: A qualitative review of the clinical law module at the Howard College Campus" (2006) 2 De Jure 252 at 265-6 where the author endorses a view by Fox that "law schools exist to produce and deliver legal education in order to satisfy societal needs and demands for legal services". 
to applied practice skills. ${ }^{25}$ Roy Stuckey of the University of South Carolina School of Law, in formulating his five most important educational goals of clinical programmes, does not even mention practical lawering skills. ${ }^{26}$ Practical legal skills naturally do form part of what is taught during clinical programmes, but these skills are merely the tools used by the profession. Applying these tools appropriately requires a thorough understanding of what law is all about. The problem with viewing clinical programmes as merely engaging in practical skills training, is that it amounts to a reduction of the educational goals of such programmes to being a purely unreflective activity, not worthy of a place in tertiary education. So it has been suggested, by some respected academics, that legal practice (and by implication, clinical legal education) is mostly about "form-filling, formfiling and, sometimes, form-construction". ${ }^{27}$ If this is indeed what the practice of law is about, it begs the question why we need law schools at all.

The different goals of academic methodology versus clinical methodology may be illustrated with the aid of following example:

During academic study, the law of contract is typically taught (1) with a view to systematically teach students the body of law applicable to contract (knowledge of substantive law); (2) the manner in which the courts have applied specific aspects thereof (analytical skills and legal reasoning); (3) some reflection on how constitutional values may impact on the law of contract (reflection on values and justice) and (4) be required to write an exam or essay to demonstrate knowledge (writing skills).

In the law clinic a student dealing with a dispute founded on contract will be taught: (1) how to recognise the relevant facts and applicable law (applied research skills and analytical skills); (2) the content of the specific legal rules applicable (knowledge of substantive law); (3) the ability to formulate a legal strategy in order to advance the client's case based on the applicable law (problem solving skills); (4) the ability to gather relevant information and evidence to support the client's case (factual investigative skills); (5) the ability to initiate appropriate legal procedure in order to advance the case (knowledge of procedural law); (6) the ability to draft the required documents (drafting skills); (7) the ability to quantify the client's claim (numeracy skills); (8) the ability to counsel the client throughout the process (client counselling skills); (9) the ability to act in a professional and ethical manner in completing the process (knowledge of professional rules and values); (10) the ability to engage in this process in the context of a law practice, working with partners, supervisors and secretaries (learning and working in groups); (11) the ability to see and experience the needs of the poor and use of law to facilitate social justice (values and the role of lawyers in society) and finally (12) the ability to look back on the entire process in order to understand what happened and why, to evaluate choices made, to form connections and to gain insight into their own performance and the process (reflection).

25 The seven goals of clinical legal education are said to be: (1) professional responsibility; (2) judgment and analytical ability; (3) knowledge of substantive law; (4) applied practice skills; (5) provision of legal services; (6) working in groups; and (7) integration of the goals. See Elsabe Steenhuisen "The goals of clinical legal education" in De Klerk (ed) Clinical Law in South Africa 2nd ed (2006) 263 at 266 and further.
26 Op cit note 19 at $50-1$. Stuckey's five educational goals are: (1) Developing problem-solving skills; (2) Becoming more reflective about legal culture and lawyering roles; (3) Learning how to behave as well as how to think as a lawyer; (4) Understanding the meaning of justice and the responsibility of all lawyers to strive to do justice; and (5) Discovering the human effects of the law.

27 Woolman et al op cit note 16 at fn 53. 
Clinical programmes are not the same as articles of clerkship or pupilage at the Bar. ${ }^{28}$ At the Wits Law Clinic, as at many other clinics around South Africa, we do both. Quite often, we engage as article clerks the same students who completed the clinical programme the year before. There is a vast difference in the training of article clerks and the teaching of students in the clinical programme. It is incorrect to say that clinical programmes are superfluous or expendable at university level, because it is something that will in any event be taught during articles. Students in a clinical programme are subjected to close supervision with structures in place to prevent harm to clients. Every act by the student is, or should be, subject to scrutiny. Students cannot be held professionally accountable for what they do. Post graduate professional training, on the other hand, takes place with very little structured supervision. It takes place in an uncontrolled environment dominated by commercial and other considerations and much of it entails a general socialisation into practice. Articled clerks or interns are registered with the law society; they are subject to professional rules and can be held accountable for what they do. Not only are post graduate training and clinical programmes different in practice, they have entirely different goals. Upon completion of articles, a candidate attorney would have passed a national admission exam, be admitted to membership of a professional society and be allowed to render professional services to the public. Clinical programmes aim at achieving none of these results. What clinic does aim to do, in conjunction with academic legal education, is to produce a law graduate that is competent to engage in professional training with a view to admission, or to choose another career whilst having a firm grasp of law and its application in practice. Academic legal education alone, cannot achieve this goal.

Clinical legal education and academic legal education are two sides to the same coin. Without the one the other cannot profess to achieve the stated outcomes of the LLB degree. It is like those old vinyl records, seven inch singles they were called, which contained the artist's popular hit song on one side and a lesser known, maybe more experimental, song on the flip side. The flipside song showed what the same artist is capable of. It took the listener out of the comfort zone of keeping the beat to a hit song. Not everyone liked the flipside song but it did serve to develop the listener's taste in music and perhaps even stimulated the listener to experiment with other tunes. Clinical education is the flipside of academic education. Without it, there is nothing to compare academic education to and nothing to contextualise the theory of law. When these graduates enter practice, an entirely new record is put on the turntable with tunes so strange and different from those played at university, that they are utterly bewildered. Such a one-sided and insulated education could surely not profess to be adequate.

Clinical legal education is not a novelty and neither is the institutional prejudice against it. Ninety years ago William Rowe had already formulated the need for and value of clinical education in the law degree. ${ }^{29}$ In 1947 Jerome Frank observed that law schools in the United States continue to shun anything to do with the practice of law "as if courts and lawyers would infect students with intellectual bubonic plague." ${ }^{30}$ Frank equated the (then current) teaching methods in US law

28 In the traditions of the split bar legal profession adopted from the English practice, articles of clerkship for the attorneys profession and pupilage for the advocates profession is required for entry to the respective professions.

29 See the discussion of an article by William V Rowe entitled "Legal Clinics and Better Trained Lawyers -
A Necessity" (1917) Ill. L.R. 591, by Phillip Plowden "No new thing under the sun?", paper delivered at the Fourth International Journal of Clinical Legal Education Conference held at London during July of 2006 (copy with author).

30 Jerome Frank "A Plea for Lawyer-Schools" (1947) The Yale Law Journal 1303 at 1313. 
schools to "future horticulturalists who restrict their studies to cut flowers" and to "prospective dog breeders who never see anything but stuffed dogs." 31 Things are not much different today. ${ }^{32}$ I submit that the only thing controversial about clinical education is its continued relegation to the backbenches of legal education and its almost unique absence when compared to the university education in other professions ${ }^{33}$.

There is another reason why clinicians are not regarded as regular academics. A large part of the work of academics, entails research and publication which, besides teaching, is the life blood of academia. From the early seventies when clinics first made their appearance in South Africa, until the end of the nineties, very little in the way of publications emanated from local clinics. During this time, there were only a handful of local journal articles dealing with clinical legal education, all written by only two or maybe three authors. ${ }^{34}$ One may be forgiven for thinking that these authors verbalised the views of all clinicians in South Africa. In reality, the clinical movement was developed by many full-time clinicians who were hard at work, doing everything except publish. It is therefore most encouraging to see the amount of journal articles published during the past few years by practicing clinicians around South Africa. ${ }^{35}$

31 Ibid

32 The underlying prejudice against educating students for practice was illustrated during a discussion at a law school staff meeting at the University of the Witwatersrand during 2007. The background to this discussion was continued criticism of law schools by the organized profession for failing to teach students certain skills identified as lacking amongst young practitioners, and in particular numeracy skills. The discussion during the staff meeting was prompted by a survey which law schools were asked to complete, detailing the numeracy training offered in the law degree. There appeared to be immediate resistance to the idea that law schools should be held accountable in this regard. Comments included statements to the effect that it is not the law schools fault that numeracy skills are lacking; that it not the law schools responsibility to address this problem, that there is no time in the four-year degree to engage in skills at this level; that it has not been shown that law students at Wits really need such training and that it is not the purpose of the law degree to educate students for practice.

33 The criticism that law has lagged behind other professions has been raised by many, including William Rowe (op cit note 26 at fn 5-6); Church (op cit note 16 at 164) and Chaskalson (op cit note 16 at 116) to name but a few.

34 By far the most prolific writer on clinical legal education in South Africa, is professor David McQuoid-Mason from the University of KwaZulu Natal. See for example "Clinical Legal Education:
Its future in SA" (1977) 40 Tydskrif vir die Hedendaagse Romeins-Hollanse Reg 343; An outline of legal aid in South Africa (1982) Juta \& Co; "The organisation, administration and funding of legal aid clinics in South Africa" (1986) 1 Natal University Law and Society Review 189; "Teaching social justice to law students through community service: The South African experience" in P.F. Iya et al (eds) Transforming South African Universities (1999) at 89. Other South African authors on clinical education during this period include Philip F. Iya and Joan Church.

35 During the past few years many active clinical teachers have had their research published in accredited law journals in South Africa. The published research covers areas such as clinical methodology (see for example Y Vawda "Learning from Experience: The Art and Science of Clinical Law" (2004) Journal for Juridical Science 116 and "Lost in Translation: Language and diversity issues in clinical law teaching" (2006) De Jure 295); the role of clinical teaching in the law degree (see for example W. de Klerk "University law clinics in South Africa" (2005) South African Law Journal 929 and "Integrating Clinical Education in the Law Degree: Some thoughts on an alternative Model" (2006) De Jure 244); quality review and assessment methods (see M. Osman "Meeting quality requirements: A qualitative review of the clinical law module at the Howard College Campus" (2006) De Jure 252); substantive law dealt with at clinics (see for example R du Plessis "A Consumer Clinic as a Specialised Unit" (2006) De Jure 284 and case note by P. Jordi De Jure 455) and many others. 
Through research into areas such as clinical methodology, the structure of clinical courses, the educational outcomes and quality control measures, clinical programmes can only improve. Through research into areas of applied substantive law, the specialised practices of clinics will become even deeper and the students will benefit from working with lawyers who are experts in their field of practice. In order for clinicians to up their publication output, law schools must however be accommodating. The average contact time of clinical teachers at Wits Law School is at least double that of academic teachers ${ }^{36}$ on top of which client files must be maintained during university vacations. The realities of clinical practice must be borne in mind by law schools when setting research targets for clinical teachers.

In conclusion, it must be said that in South Africa there has been significant progress in the acceptance of law clinics by the legal profession and academia over the past 35 years, since clinics first made their appearance. ${ }^{37}$ Every law school in South Africa offers a clinical programme and at more than half, the completion of the programme is compulsory for degree purposes. ${ }^{38}$ Some clinics are more fortunate than others and enjoy remarkable support from their law schools. Yet, the tolerance of clinics at South African law schools, I suspect, has a lot to do with the legal services they provide and not their educational value. The disparate conditions under which most clinicians are employed, is evidence to this effect. Much of the strength of law clinics in South Africa is drawn from their role in providing access to justice to the poor. Access to justice is indeed a pressing issue in South Africa where clinics have played, and continue to play, a very important role. But university law clinics are often still referred to as "legal aid clinics" 39 and even the association of law clinics in South Africa, AULAI, still bears this label. Many of the early writers on clinical legal education in South Africa likewise preferred to use the term 'legal aid clinics' in reference to university law clinics. This preoccupation with law clinics as 'legal aid institutions' has resulted in a concrete ceiling being imposed on their educational activities.

As the clinical movement in South Africa approaches the end of its fourth decade of existence, one could only hope that the irrational prejudice against clinical legal education will come to an end and that clinical educators will be afforded equal partnership in the law school alongside their academic counterparts. Perhaps then law schools could produce graduates that are truly prepared for entry to the legal profession.

36 I am told that the average contact hours of law school academics at the University of the Witwatersrand Law School is eight hours per week. The average contact hours of clinical teachers during 2007 is 23 hours per week, in addition to which candidate attorneys must be supervised and client files must be dealt with throughout the year.

37 For a discussion of the development of law clinics in South Africa see Willem de Klerk "University
Law Clinics in South Africa" (2005) 122 South African Law Journal 929 at 930-2.

38 Association of University Legal Aid Institutions (AULAI) Annual Report (2003) (copy on file with author).

39 The law clinic at the University of the Western Cape, for example, was known until very recently as the "UWC Legal Aid Clinic". 